\title{
Relationship between Perception of Stakeholders about Corporate Social Responsibility Program Benefits and Reputation of Indonesia Power Company
}

\author{
Agus Naryoso $^{1}$, Sri Widowati Herieningsih ${ }^{2}$ \\ \{agusnaryoso@gmail.com ${ }^{1}$, herieningsih@gmail.com² \\ Universitas Diponegoro, Indonesia ${ }^{1,2}$
}

\begin{abstract}
PT. Indonesia Power Plant Unit Semarang has carried out its obligations as a company by carrying out Corporate Social Responsibility in accordance with Law Number 40 of 2007. Article 74 paragraph (1) reads as follows \& quot. Companies that carry out their business activities are funded or distributed with Natural Resources, Social Responsibility with the Environment \& Quot. Thus, many people are helped by the existence of CSR from PT Indonesia Power. The Objectives this study is to know Relationship Between Perception of Stakeholders About Corporate Social Responsibility Program Benefits and Reputation of Indonesia Power Company. Based on hypothesis testing conducted using Pearson's analysis shows there is a relationship between CSR Benefits and Reputation Companies. Evidenced by the significance coefficient value of 0:00. From the results of the analysis Obtained simply between the benefits with the company Obtained (r) is 0 .
\end{abstract}

Keywords: Corporate Social Responsibility, Public Relations, Corporate Reputation.

\section{Introduction}

Corporate Social Responsibility (CSR), a public relations program, is a form of company contribution for sustainability of community's life surrounding the company, both socially, economically and environmentally, as well as a form of public relations tools to build a business reputation. Corporate Social Responsibility (CSR) has many positive impacts to the company that can maintain or boost the company's reputation and brand image. Through this activity the company will get a social license to operate, reduce the company's business risk, expand access to resources, reduce costs, improve relations with stakeholders, improve relations with regulators, increase employee morale and productivity as well as opportunities to get rewards.

Corporate Social Responsibility (CSR) activities are important for the sustainability of a company which is carried out through programs to accommodate the public interest. Corporate Social Responsibility (CSR) is part of Community Relations activities that deal directly with real social problems faced by communities around the organization. Through the Community Relations approach, the organization together with the surrounding community tries to identify solutions and implement action plans for the problems encountered [1].

Indonesia Power has a vision; Become a reliable energy company that grows sustainably, through a Mission; Conducting Power Plant Business and Related Services that are environmentally friendly. As a form of social activity carried out by the Indonesia Power Plant 
Unit Semarang, in carrying out the Corporate Social Responsibility (CSR) programs they are committed and responsible by designing programs that have positive impacts to the community around the Indonesia Power Plant Unit Semarang, which are important values for the company. Those are carried out as a form of corporate social responsibility which is realized through various social activities for people who live around Indonesia Power Plant Unit Semarang.

The social aid program has several sectors that are carried out, such as economics, environmental, educational and social sectors. It is designed based on company's ability and needs of target communities, and conducted regularly every year. Indonesia Power UP Semarang also divides the CSR distribution areas into three CSR target areas, not only for the area closest to the Power Plant Unit, but this CSR is also targeted at areas outside the ring with the intention of developing aids and considering equal distribution of aids in Semarang area.

Some CSR activities had been carried out by Power Plant Unit Semarang for surrounding communities so that they realized CSR benefits, both direct and indirect benefits. Direct benefits, the activities improved family economic quality, indirect benefits; they advanced potential of local communities. The main target remained to focus on the communities closest to the location of the company, because the communities around company's location are a major priority for the company. Commitment and community support will provide continuity on the organization's activities to achieve the business objectives of Indonesia Power. In fact, the business carried out spending a lot of money did not get a significant positive response. In turn, There were still some negative issues in public because some people around the company location complained that they did not get the impact of CSR, they considered that Indonesia Power designed programs that did not touch the substance of the problem and did not suitable with the primary needs of the target communities. The programs only lasted for a limited period of time, and the amount of funds distributed was relatively limited. In addition, more beneficiaries were also given to entrepreneurs who had already had businesses that had run well for a long time, while entrepreneurs who will to start businesses or small entrepreneurs who needed assistance tend to be ignored. Lack of perceived benefits will potentially form a negative perception of the community and correlated well with the company's reputation. The method use was explanatory survey, populations is the CSR Program beneficiary communities, the number of samples was 30 people by non-random method, data were process using crosstab.

Stakeholder perception is opinions or views of people towards something. Between individuals and other individuals may have different opinions. Perception is influenced by feelings, thinking abilities and experiences of individuals who are difference from each other. Reputation is a value given to individuals, institutions or countries. Reputation cannot be obtained in a short time because it has to be built up for years to produce something that can be appreciated by public. Reputation will be able to survive if it has sustainable and consistent values between words and actions [2]. This paper was made using data from research results using an exploratory approach, research results were obtained by conducting interviews with 30 respondents who were affected by exposure to CSR activities and or beneficiaries of CSR activities Indonesia Power UP Semarang. Data analysis was conducted through process of coding, editing and tabulating data, while correlations test to determine the relationship between variables using the Pearson correlation test. Based on the description above, the problems that we can formulate are as follows: Is there a relationship between stakeholder perceptions about the benefits of the Corporate Social Responsibility programs and the reputation of the Indonesia Power company? 


\section{Data Analysis and Discussion}

The objective of this study is to determine the relationship between stakeholders' perceptions about the benefits of Corporate Social Responsibility and the reputation of the company Indonesia Power UP Semarang. Based on data that collected completely through questionnaires, the researchers then conducted quantitative analysis or often referred to statistical data analysis. Data from the results of research on the relationship between the relationship between Stakeholder Perceptions of Benefits Corporate Social Responsibility (CSR) programs and the Indonesia Power Company reputation, this study obtained 30 respondents who had been spread around areas that were exposed to the Indonesia Power UP Semarang CSR activities. Sampling of 30 respondents had completed the element of representation for a large unknown number of populations.

The results of coding all the perception variable questions about Benefits CSR programs has gotten result, $86.3 \%$ of respondents had positive perception of the CSR programs benefits conducted by PT. Indonesia Power UP Semarang. It can be seen from several aspects such as; benefits of CSR activities on poverty reduction were appraised by respondents, as many as $80 \%$ success in reducing poverty level of CSR targeted community of Indonesia Power UP Semarang, in this aspect the respondents can prove that their quality of life had increased after getting help from Micro, Small and Medium business (UMKM) and the management of UMKM developed regularly to create jobs and reduce unemployment in surrounding social environment. Almost all respondents agreed that CSR aids really contributed positively to economy of local community.

Then $73 \%$ of respondents gave a positive appraisement of CSR activities benefits for increasing family income, the CSR programs was considered capable of making some of the community members earned extra income so they were able to overcome family economic problems, the respondents said that the activities of the CSR programs made them easy to supply economic needs, although they had not opened their own businesses yet, they can work in neighboring business who had gotten help from the Indonesia Power Up Semarang CSR. The benefits for UMKM management in addition to get equipment and capital support, beneficiaries also had opportunity to exhibit and market the UMKM production more broadly, thus helping them to expand their target market.

Corporate social responsibility activities are considered capable of reducing the impact of environmental pollution. $73 \%$ of respondents said that the activities in the form of wastewater management helped people to get clean living environment. The consideration was based on the assumption that local communities also had negative potential for operational impact of Indonesia Power. The efforts to help create a clean environment was carried out by creating program of environmentally friendly industry support by providing water management installation for factory industrial waste in Kampung Batik Malon, and Ijo Royo-Royo. There were some people, maximum of $7 \%$ who had not felt the prevention of environmental pollution impact, but the company tried and committed to provide the CSR equally.

PT. Indonesia Power Up Semarang implemented various CSR activities that pay attention to primary needs of the target including those related to local culture development. In connection with the benefits of CSR activities towards the development of local cultural potential, the research finding indicated that majority of respondents gave a positive score with the interpretation of appraisement was very good. The focus of the local culture developed through CSR of PT. Indonesia Power UP Semarang focused on efforts to develop Batik. The policy was one of support for Government's development and strategic plan to develop Semarang's Batik as one of characteristics. The developed local cultural was an 
arrangement of the Kampung Batik Malon. The majority of respondents, $90 \%$ said that the idea to preserve Batik Malon was a new breakthrough in maintaining local culture, profits were not only based on sales profits, but also introducing local batik to be more preferred and become part of young people's lifestyle.

Benefits of CSR in creating economic independence were agreed by $100 \%$ of respondents, they considered that these activities were going well. Economic independence refers to the ability to develop business independently. Manage financial management, allocate development funds, and not merely rely on CSR funds. Independence also provides opportunities for UMKM to make innovation and breakthrough through products diversification or target markets expansion. CSR activities aids also supported the addition of assets and capital turnover, so they got opportunity to apply for credit loans at the Bank because creditor considered that debtor had good credibility.

Further evaluation related to the benefits of the company's CSR activities in UMKM development received good responses, 96\% respondents thought they were very enthusiastic because CSR provided aids in the form of batik tools, and training in production of Batik Alam. People said that they were helped very much in their business development because of the aids. Batik is not only produced by writing mechanism, but also produced by using printing equipment, so that it can be mass produced. Based on the respondent's explanation, the aids were able to become an effective UMKM Empowerment model, and to encourage economic growth, to reduce poverty, and to reduce unemployment. Initially, before given aids, the number of batik craft maker was only in two houses and after given supports, it expanded to 20 houses.

Improving technology skills in supporting community entrepreneurship is also one of the flagships CSR activities carried out by PT. Indonesia Power UP Semarang. The community considered that the presence of CSR Indonesia Power made respondents more technologically literate, especially those related to the latest technological equipment that supported entrepreneurship activities. The focus of corporate CSR, as mentioned by almost some respondents, more emphasized on introduction and utilization of the latest technology in production. A number of $90 \%$ respondents told that they had better skills, initially, those who could not make batik became able to make batik and operated batik printing machines, those who did not have ability to vacuum fish became able to vacuum fish. People who did not have business idea of waste materials became an expert to make souvenirs using used waste materials.

The benefits of CSR were believed to be able to build a tough business spirit, $90 \%$ of respondents reported that they had good skills with competitive and quality final results. Skills are not only about management but also development and diversification of superior products. Respondents felt the benefits of CSR activities were considered good in improving the quality of the health of surrounding community, the company's commitment was demonstrated by providing chimney aids at house that produced smoked fish, recycling factory waste into sterile water from chemicals to be used as a source of community environmental management. This was very helpful in reducing the number of cases of acute respiratory infections (ARI). Some people said that with the programs, people with ARI tended to decrease from year to year, and they could use sterile wastewater for environmental management activities such as watering plants, and the water did not pollute the oceans.

CSR provided benefits to enhance creativity in making new innovations which through CSR assistance the community continues to be stimulated to be able to produce ideas for developing UMKM production products, such as making a variety of milkfish flavors, as well as other interesting menu variations, especially in food businesses, and also being encouraged 
in making product names, as well as being creative in choosing media for product sales. Respondents' appraisement of improving education quality benefits was felt to be less than optimal, $40 \%$ of respondents gave unfavorable responses, because indeed Indonesia Power UP Semarang was not too focused on education programs, although most of the community were very pleased with the presence of PT. Indonesia Power Up Semarang, there were still some respondents who gave unsatisfactory responses. The existence of CSR in the form of entrepreneurial support indirectly affected the better family economic quality, but there was fantastic praise, as much as $17 \%$ of respondents admitted that with the business they ran, they can pay for children to continue their education to college.

Regarding the benefits of CSR in improving quality of public infrastructure, it can be concluded that the majority of respondents agreed that Indonesian CSR helped improve public infrastructure, $70 \%$ of respondents said that Indonesia Power had made LED floodlights to all Pos Kamling in Tanjung Emas Sub-District, Semarang. In addition, CSR Indonesia Power supplied the tools needed by UMKM, for example supplying oven equipment to reduce water content in Presto milkfish before being packaged at Milkfish Management UMKM.

Furthermore, a number of $87 \%$ of respondents rated the benefits of CSR activities in improving management skills successfully, they claimed that they did not find difficulties to manage and prepare financial reports, after receiving training. When they were asked to describe the process, they can provide a good explanation, first, separate business finances from personal money. Second, determine the percentage of financial that will be used for business needs. Third, keep bookkeeping in order to control all financial transactions, both income, expenses, and debt and receivables. Fourth, reduce the risk of business debt. And the fifth is control of the smooth cash flow of the business. Other benefits, reducing crime got $100 \%$ good response because of collaboration between Indonesia Power and UMKM such as milkfish managers, waste bank managers, smoked fish managers, batik makers who provided employment for the community. So that unemployment decreased, this was correlated with poverty and influenced someone to commit crime.

The last benefit was the benefit in increasing the number of industrial patents also received $100 \%$ positive response. Based on the acknowledgment given by the CSR beneficiaries, the communities gave an excellent appraisement of the existence of PT Indonesia Power's CSR which helped to patent their businesses. All respondents said that their business had a good patent, meaning their business was legal and legally registered. Their patented businesses are Bandeng Duri Lunak Bu Fatkhan, Salma Batik, Zee Batik, Ikan Asap Bandarharjo, Ikan Bandeng Presto Selayang Pandang.

The hypothesis used in this study is that there is a relationship between stakeholder perceptions about the benefits of CSR programs and the reputation of the Indonesia Power Plant Company Semarang Unit. Based on the results of the Cross Tabulation, it showed that there was a tendency for relationship between the Stakeholder Perception about the Benefits of Corporate Social Responsibility (CSR) Program and the Reputation of the Indonesia Power Company. These results stated that the better the perception about the benefits of CSR carried out by the company, the more positive the company's reputation. This also applied that the worse the CSR provided by the company, the worse the company's reputation in the eyes of public. 
Table 1. Crosstab relationship between perception of stakeholders about corporate social responsibility program benefits and reputation of Indonesia power company

\begin{tabular}{|c|c|c|c|c|c|}
\hline $\mathrm{x}$ & Bad & Average & Good & Very Good & Total \\
\hline Bad & $0(0 \%)$ & $0(0 \%)$ & $0(0 \%)$ & $0(0 \%)$ & $0(0 \%)$ \\
\hline Average & $0(0 \%)$ & $1(100 \%)$ & $0(0 \%)$ & $0(0 \%)$ & $1(100 \%)$ \\
\hline Good & $0(0 \%)$ & $0(0 \%)$ & $12(52,2 \%)$ & $11(47,8 \%)$ & $23(100 \%)$ \\
\hline Very Good & $0(0 \%)$ & $0(0 \%)$ & $0(0 \%)$ & $6(100 \%)$ & $6(100 \%)$ \\
\hline
\end{tabular}

In addition, the results of the hypothesis test also proved that the perception of the company's CSR benefits was one of the factors influencing the company's reputation. This was evidenced by the Pearson correlation coefficient value which tested the correlation between the variables of Perception about the benefits of CSR and Company Reputation; the test results had a significance value of 0.00 . From the results of a simple correlation analysis the correlation between benefits and company reputation $(r)$ is 0.728 , which means the level of relationship between these variables was included in the strong category because it was close to number 1 . This showed that there was a strong relationship between the perception of the benefits of CSR and the company's reputation. While the direction of the relationship also showed a linear or positive result. The results that showed a $\mathrm{r}$ positive value, means that the more positive the perception of the benefits of CSR, the more the Company's reputation is enhanced. Conversely, the lower the CSR benefits, the worse the company's reputation. The correlation test results showed that Public Opinion theory was relevant to the research findings. This can be seen as contained in the contents of the Encyclopedia of Communication [3], if public attitudes become strong or positive then attitudes will form opinions, strong opinions will shape action. This is in line with the results of the study where there is a relationship between Stakeholder Perceptions about the Benefits of the Corporate Social Responsibility (CSR) Program and the reputation of Indonesia Power Company.

Public opinion theory is related to reputation and trust. Public opinion theory is a collection of attitude expressions from a group of individuals who have same opinion on problem that occurs. Public opinion can contain both positive and negative opinions. In this case the impulse of attitude that emerges is very strong which then makes it appear into opinion. When public opinion has been formed to be strong enough, verbal actions or behaviors will emerge. A negative attitude will give a significant contribution to the formation of the company's reputation.

People who had gotten CSR programs from Indonesia Power UP Semarang felt positive benefits and this affected the formation of perception. Perception has been being the main element forming high reputation of Indonesia Power UP Semarang, these results confirmed that Indonesia Power UP Semarang is a company with high credibility and good reputation. In addition, CSR actions that are carried out continuously make the community give a very good appraisement of Indonesia Power UP Semarang.

The results of the study showed that respondents had certain satisfaction with the company's CSR, and the results showed that the response was positive. Based on the theory of public opinion, respondents who already had high trust in companies will affect the value of a positive perception of companies that carry out CSR activities.

The quality of an abusive CSR program will greatly influence a good corporate reputation, and will have a bearing on business continuity [4]. The research findings above are related to reputation theory. There is debate about what shapes reputation, the relative importance of culture [5], design and other tangibles [6][7], advertising and public relations, 
[8][9][10] and social responsibility. From the results of research show that the theory above is proven.

\section{Conclusion}

Based on research that has been conducted by testing the Perception variable about the Corporate Social Responsibility (CSR) Program Benefits with the Reputation of the Indonesia Power Company, it can be concluded that there was a tendency to correlate between the two variables. This was when confirmed using the Pearson correlation coefficient test, the perception of the benefits of CSR and Company Reputation had a significance value of 0.00 . From the results of a simple correlation analysis there was a correlation between the perception of the benefits of CSR with the company's reputation with a value (r) of 0.728 , which meant the level of relationship between these variables was included in the strong category because it closed to number 1 . This showed that there was a strong relationship between the variable perceived CSR benefits and the company's reputation. While, the direction of the relationship was positive because the value of $r$ was positive. It means that the more positive appraisement of the benefits of CSR the more positive the Company's reputation. Conversely, the lower the perception about the benefits of CSR, the more negative the company's reputation. The better the benefits are felt, the more trust arises by the community.

\section{References}

[1] Y. Iriantara and R. K. Soenendar, Literasi media: apa, mengapa, bagaimana. Simbiosa Rekatama Media, 2010

[2] M. Basya and I. Sati, "Tantangan Indonesia Baru: Strategi \& Aktivitas Public Relations," Jakarta [ID] PERHUMAS, 2006.

[3] S. W. Littlejohn and K. A. Foss, Encyclopedia of communication theory, vol. 1. Sage, 2009.

[4] G. Davies and L. Miles, "Reputation management: theory versus practice," Corp. Reput. Rev., vol. 2, no. 1, pp. 16-27, 1998.

[5] M. Alvesson, "Organization: from substance to image?," Organ. Stud., vol. 11, no. 3, pp. 373394, 1990.

[6] W. Olins, The corporate personality: An inquiry into the nature of corporate identity. Design Council, 1978 .

[7] E. Selame, J. Selame, and F. P. Model, The company image: building your identity and influence in the marketplace. John Wiley \& Sons Inc, 1988.

[8] M. Meyers, "Mechanical Metallurgy: Principles and Applications.(Book)," Prentice-Hall, Inc., 761, p. 1984, 1984.

[9] P. J. Kitchen and R. A. Proctor, "The increasing importance of public relations in fast moving consumer goods firms," J. Mark. Manag., vol. 7, no. 4, pp. 357-370, 1991.

[10] S. L. Wartick, "The relationship between intense media exposure and change in corporate reputation," Bus. Soc., vol. 31, no. 1, pp. 33-49, 1992. 